\title{
HEALTH RISKS EVALUATION OF HEAVY METALS IN SEAFOOD
}

\author{
Zahra KHOSHNOOD * and Reza KHOSHNOOD ** \\ * Islamic Azad University, Dezful Branch, Department of Experimental Sciences, Dezful, Iran, \\ Zkhoshnood@gmail.com \\ ** Islamic Azad University, Tehran Central Branch, Young Researchers Club, Tehran, Iran, \\ RezaKhoshnood@gmail.com
}

KEYWORDS: heavy metals, fish consumption, human health risk.

\section{ABSTRACT}

Fish is an excellent, low-fat source of protein and provides many benefits, such as contributing to low blood cholesterol. Heavy metals are increasingly being released into natural waters from geological and anthropogenic sources. Due to the rapid development of agriculture and industry, and a historical lack of enforcement of regulations, the study areas have become contaminated by metals, especially cadmium $(\mathrm{Cd})$ and lead $(\mathrm{Pb})$ which has been emitted into the environment through atmospheric deposition, solid-waste emissions, sludge applications, and irrigations with wastewater.

The health risks posed to the local inhabitants by exposure to $\mathrm{Pb}$ and $\mathrm{Cd}$ in two coastal regions of Iran through the consumption of contaminated fish were investigated, based on estimated target hazard quotients (THQs). The results showed that THQ values are less than 1 for both adults and children by either group consuming fish alone.

The distribution of several heavy metals $(\mathrm{Cd}$ and $\mathrm{Pb})$ was investigated in muscle and liver in six different fish species seasonally collected in the Persian Gulf (autumn 2008 summer 2009). The concentrations of all metals were lower in flesh than those recorded in liver due to their physiological roles. The THQ index for fish was calculated. Estimation of target hazard quotients calculations for the contaminated fish consumption was calculated to evaluate the effect of pollution on human health. Total metal THQs values ( $\mathrm{Pb}$ and $\mathrm{Cd}$ ) for adults were 0.05 and 0.04 in Bushehr and Bandar-Genaveh, respectively, and for children was 0.08 and 0.05 in Bushehr and Bandar-Genaveh, respectively.

The dietary intake of $\mathrm{Pb}$ estimated for the inhabitants in this area is far below the limit considered tolerable. The Cd intake through the consumption of fish is also less than the limit of daily dietary intake considered tolerable by FAO/WHO.

RÉSUMÉ: L'évaluation des risques pour la santé des métaux lourds présents dans les produits alimentaires d'origine marine.

Le poisson est un aliment excellent, une source de protéine maigre qui offre des nombreux bénéfices, tel que la contribution à la diminution du taux du cholestérol dans le sang. Les métaux lourds sont de plus en plus présents dans l'eau en provenance des sources géologiques et anthropiques. Dû au développement rapide de l'agriculture et de l'industrie ainsi qu'au manque historique d'application de la législation, la zone d'étude est devenue contaminée par des métaux lourds, plus particulièrement par le cadmium $(\mathrm{Cd})$ et le plomb $(\mathrm{Pb})$ qui se sont retrouvées dans le milieu en provenance des poussières atmosphériques, des déchets solides, des application des boues des usines de traitement des eaux usées ainsi que due à l'irrigation des cultures avec de l'eau usée. 
Les risques pour la santé représentées par l'exposition au $\mathrm{Pb}$ et au $\mathrm{Cd}$ des habitants de deux régions côtières d'Iran par la consommation des poissons contaminés ont été investigués en utilisant les quotients de danger cible estimés (les THQs). Les résultats ont montré que les valeurs THQ sont moins de 1 pour les adultes tout comme pour les enfants si la consommation de poisson est la seule prise en compte.

On a étudié la distribution de ces deux métaux lourds $(\mathrm{Cd}$ et $\mathrm{Pb})$ dans le tissu musculaire et le foie de six espèces de poissons différentes collectées de manière saisonnière dans le Golfe Persique (automne 2008 - été 2009). Les concentrations de tous les métaux ont été plus faibles dans le muscle que dans le foie, due aux rôles physiologiques différents des deux organes. L'indice THQ pour poissons a été calculé. L'estimation des quotients de risque cible pour la consommation de poisson contaminé a servi aux calculs de l'évaluation de l'effet de la pollution sur la santé humaine. Les valeurs totales des THQ des métaux étudiées ( $\mathrm{Pb}$ et $\mathrm{Cd}$ ) pour les adultes ont été de 0,05 à Bushehr, et respectivement de 0,04 à Bandar-Genaveh, pendant que pour les enfants, les valeurs ont été de 0,08 à Bushehr et de 0,05 à BandarGenaveh.

L'apport alimentaire de $\mathrm{Pb}$ estimé pour les habitants de la zone se trouve bien en dessous des limites admises. Cela va de même pour l'apport alimentaire de $\mathrm{Cd}$ à travers le poisson, qui est moindre que la valeur établie par FAO et OMS en tant que limite admissible pour l'apport alimentaire journalier.

REZUMAT: Evaluarea riscurilor pentru sănătate reprezentate de metalele grele din alimentele de origine marină.

Peștele este o sursă de proteine excelentă, cu conținut scăzut de grăsimi, consumul său contribuind la scăderea concentrației colesterolului în sânge. Din păcate, o cantitate din ce în ce mai mare de metale grele provenind din surse geologice și antropice se acumulează în acvatoriile naturale. Datorită dezvoltării rapide a agriculturii și industriei pe fondul unei neglijări istorice în aplicarea legislației pentru protecția mediului, zonele studiate au fost contaminate cu metale, în special cu cadmiu $(\mathrm{Cd})$ și plumb $(\mathrm{Pb})$. Acestea au provenit din depunerea pulberilor atmosferice, din deșeuri solide, din aplicări de nămol și irigații cu apă uzată din stațiile de epurare.

S-au investigat riscurile existente pentru sănătatea locuitorilor a două regiuni de coastă din Iran, cauzate de expunerea $\mathrm{la} \mathrm{Pb}$ și $\mathrm{Cd}$ prin consumul de pește contaminat. În acest scop s-au folosit coeficienți de risc țintă (THQ). Valorile găsite pentru acești coeficienți au fost mai mici de 1, atât pentru adulți, cât și pentru copii, dacă s-a luat în considerare ca unică sursă de contaminare peștele consumat.

S-a studiat distribuția acestor metale grele $(\mathrm{Cd}$ și $\mathrm{Pb})$ în țesutul muscular şi în ficatul a şase specii diferite de pește colectate sezonier în Golful Persic (toamna 2008 - vara 2009). Concentrațiile găsite au fost mai mici în țesutul muscular decât în ficat, datorită rolului lor fiziologic diferit. S-au calculat indicatorii THQ pentru pește, iar estimările obținute pentru consumul de pește contaminat au fost folosite pentru măsurarea impactului poluării asupra sănătății umane. Valorile totale ale THQ pentru metalele investigate $(\mathrm{Pb}$ și $\mathrm{Cd})$ la adulți au fost de 0,05 la Bushehr și, respectiv, 0,04 la Bandar-Genaveh, iar pentru copii au fost de 0,08 la Bushehr și respectiv de 0,05 la Bandar-Genaveh.

Aportul alimentar de $\mathrm{Pb}$ estimat pentru locuitorii acestei zone se găsește mult sub limita admisibilă. De asemenea, și aportul de $\mathrm{Cd}$, provenit din consumul de pește, se găsește sub limita admisibilă pentru aportul zilnic alimentar fixat de FAO/OMS. 


\section{INTRODUCTION}

Fish is an excellent, low-fat source of protein and provides many benefits, such as contributing to low blood cholesterol (Anderson and Wiener, 1995). Fish contains omega-3 $(n-3)$ fatty acids that reduce cholesterol levels and the incidence of heart disease, stroke and preterm delivery (Daviglus et al., 2002; Patterson, 2002). Fish constitutes an important source of proteins, minerals, vitamins and unsaturated essential fatty acids (PUFAs), especially omega-3 PUFAs.

Scientific data indicate that fish consumption reduces the risk of coronary heart disease, decreased mild hypertension and prevents certain cardiac arrhythmias (Kris-Etherton et al., 2002). At the same time, seafood consumption has been reported as an important route of human exposure to a variety of chemical contaminants (Storelli, 2008).

Protection of human health against diseases and injuries caused by heavy metals present in the environment is one of the ultimate goals of risk assessment. Diet is a major route for human exposure, especially through consumption of fish from contaminated waters such as the Persian Gulf is (Mora et al., 2004).

The rights of all human individuals to a safe and adequate diet were expressed at the World Health Organization Forum in 2007 which led to the Beijing Declaration (WHO, 2007). This Declaration, adopted by over fifty countries, stresses the importance of a safe diet and provides guidelines for food controls that should be asserted by each country. Over the past three decades, organizations have been developed to support food safety through assessment of food contamination along with issuing food contamination alerts and recalls where necessary (Hugas et al., 2007).

Metals tend to accumulate in aquatic organisms, and concentrations of some metals can be magnified through the food webs. Humans can be exposed to metals through their diet, and over time metals can accumulate to potentially toxic concentrations (Sofuoglu and Kavcar, 2008).

With the exception of occupational exposure, fish are acknowledged to be the single largest source of heavy metals for humans. In some instances, fish catches were banned for human consumption because their total mercury content or other metals content (like as cadmium) exceeded the maximum limits recommended by the FAO and WHO (FAO/WHO, 1972).

Due to the rapid development of agriculture and industry, and a historical lack of enforcement of regulations, the studied areas becomes contaminated by metals especially including $\mathrm{Cd}$ and $\mathrm{Pb}$, which have been emitted into the environment through atmospheric deposition, solid-waste emissions, sludge applications, and irrigation with wastewater.

The suburban and urban areas of Bandar-Abbas and Bandar-Lengeh cities of Iran, are polluted by some sources of heavy metals, but information on the health risks of these elements is quite limited. The main objective of this study is to estimate the health risks of heavy metals, such as $\mathrm{Pb}$ and $\mathrm{Cd}$, via consumption of fish to the general public in the above districts by using the target hazard quotient (THQ) concept.

\section{MATERIAL AND METHODS}

Fish samples were collected along the coast of the north Persian Gulf. Six species, Lutjanus johnii, Lutjanus lemniscatus, Liza subviridis, Sillago sihama, Acanthopagrus latus and Pampus argentus have been caught from autumn 2008 to summer 2009. These six fish species were collected from two fishery regions, Bandar-Bushehr and Bandar-Genaveh. The 
fish species were randomly collected from commercial catches that landed at the local fishing ports. Immediately after the collection, fish samples were stored on ice in an isolated box and transferred to the reference laboratory of the Hormozgan environmental deputy. Body weight and length of fishes were measured. A part of the dorsal muscle from each was dissected as a sample. The fish liver tissue was also removed and prepared for processing. All of the samples were dried at $60^{\circ} \mathrm{C}$ for $48 \mathrm{~h}$ in a laboratory oven (Crinnion, 2000).

All glass wares were cleaned by soaking in $10 \% \mathrm{v} / \mathrm{v} \mathrm{HNO}_{3}$ for $12 \mathrm{~h}$ and then rinsing with ultra-pure water. Between 0.2 and $0.4 \mathrm{~g}$ of dried sample material were weighed and then digested in acid-cleaned teflon microwave vessels with $5 \mathrm{ml}$ of ultra-pure nitric acid $(65 \% \mathrm{v} / \mathrm{v})$. A microwave digester was used for 30-40 min at a target digestion temperature of $200^{\circ} \mathrm{C}$, after which that the samples were cooled $1 \mathrm{~h}$. The digested samples were transferred to a graduated plastic test tube and brought up to volume $(50 \mathrm{ml})$ with Mili-Q-water. (Chien et al., 2002)

Statistical analyses were done using the SPSS software (version 11.5). The data were tested to check normality using the Kolmogorov-Smirnov test, which showed that they have normal distribution. Pearson's correlation test was used to assess any significant relationship of $\mathrm{Cd}$ concentration in tissue with fish length and weight (level of significance, $\mathrm{p}<0.05$ ). In addition, the paired sample t-test was used to compare tissue $\mathrm{Cd}$ concentrations between stations.

The health risks through consumption of fish by the local inhabitants were assessed based on the THQ. A THQ below 1 means that the exposed human population is unlikely to experience obvious adverse effects. The methodology for estimating THQ is described in details by the US EPA (US EPA, 2000a). The dose calculations were carried out by using the standard assumption from an integrated US EPA risk analysis considering an average adult body weight of $55.9 \mathrm{~kg}$, and $32.7 \mathrm{~kg}$ for children. The health risks were separately considered the contact pathway with each exposure medium (e.g., food) changes with age. Furthermore, children are more sensitive to pollutants. There will be a certain amount of discrepancy in health risks between age groups and the locality of the inhabitants. In this respect, the THQ was determined based on the methods of Chien et al. (2002) described by the equation:

$$
T H Q=\frac{E_{F} E_{D} F_{I R} C}{R_{F D} W_{A B} T_{A}} \times 10^{-3}
$$

$\mathrm{E}_{\mathrm{F}}$ is exposure frequency (365 days/year); $\mathrm{E}_{\mathrm{D}}$ is exposure duration (70 years), equivalent to the average lifetime in Iran; $\mathrm{F}_{\mathrm{IR}}$ is food ingestion rate ( $\mathrm{g} / \mathrm{person} /$ day); $\mathrm{C}$ is metal concentration in food $(\mathrm{Ag} / \mathrm{g}) ; \mathrm{R}_{\mathrm{FD}}$ is the oral reference dose $(\mathrm{mg} / \mathrm{kg} /$ day $) ; \mathrm{W}_{\mathrm{AB}}$ is average body weight $(55.9 \mathrm{~kg}$ for adults and $32.7 \mathrm{~kg}$ for children) and $\mathrm{T}_{\mathrm{A}}$ is averaging exposure time for noncarcinogens (365 days/year number of exposure years, assuming 70 years in this study).

It was further assumed that cooking has no effect on the toxicity of heavy metals in seafood (Cooper et al., 1991; Chien et al., 2002).

For adult inhabitants of the two studied areas, the daily fish consumption was 19.17 $\mathrm{g} /$ person/day and $14.06 \mathrm{~g} /$ person/day for children.

Mean concentration of $\mathrm{Pb}$ and $\mathrm{Cd}$ for fishes in the two studied areas are presented in table number 2. Because the residents of the two studied areas consume six fish species, we used the average of heavy metal concentrations to calculate THQ. 


\section{RESULTS}

Mean concentration of $\mathrm{Pb}$ ranging from 0.09 to $0.55 \mu \mathrm{g} / \mathrm{g}$ in Bandar-Bushehr and 0.01 to $0.3 \mu \mathrm{g} / \mathrm{g}$ in Bandar-Genaveh, and for Cd, ranging from 0.02 to $0.4 \mu \mathrm{g} / \mathrm{g}$ in Bandar-Bushehr and 0.01 to $0.32 \mu \mathrm{g} / \mathrm{g}$ in Bandar-Genaveh. The average concentrations of the two metals are higher in Bandar-Bushehr than in Bandar-Genaveh. This situation exist mainly due to the unmanaged shipping activities, river runoff, and untreated sewage discharge by coastal settlements, and dumping of toxic and industrial wastes into the sea which occur adjacent of Bandar-Bushehr. Since fish catching in the surrounding district area are randomly sold and use for food by the residents of the two areas, and this six selected fish are usually eaten by the people, averaged heavy metal concentrations in fish were used for THQ calculation.

Table 1: Biometry results of fish samples.

\begin{tabular}{|c|c|c|c|c|c|c|}
\hline \multirow{2}{*}{\begin{tabular}{c} 
Species \\
\multirow{2}{*}{$\begin{array}{c}\text { Lutjanus } \\
\text { johnii }\end{array}$}
\end{tabular}} & Station & Length & Weight & \multicolumn{3}{|c|}{ No. of samples } \\
\cline { 3 - 7 } & Busheher & $24.5-36.5$ & 32.3 & $240-710$ & 585 & 10 \\
\cline { 2 - 7 } $\begin{array}{c}\text { Lutjanus } \\
\text { lemniscatus }\end{array}$ & Genaveh & $24-41$ & 32.1 & $209-1010$ & 604 & 10 \\
\cline { 2 - 7 } & Busheher & $39-58$ & 48.1 & $754-2650$ & 1672 & 10 \\
\hline \multirow{2}{*}{$\begin{array}{c}\text { Sillago } \\
\text { sihama }\end{array}$} & Genaveh & $31.5-1$ & 43.0 & $497-2286$ & 1309 & 10 \\
\hline \multirow{2}{*}{$\begin{array}{c}\text { Liza } \\
\text { subviridis }\end{array}$} & Genaveh & $11-20$ & 16 & $90-215$ & 143 & 10 \\
\cline { 2 - 7 } & Gusheher & $16-26$ & 21.7 & $150-470$ & 310.5 & 10 \\
\hline \multirow{2}{*}{$\begin{array}{c}\text { Acanthopagrus } \\
\text { latus }\end{array}$} & Busheher & $23-39$ & 27 & $234-321$ & 268.5 & 10 \\
\cline { 2 - 7 } & Genaveh & $26-41$ & 32 & $251-345$ & 273 & 10 \\
\hline \multirow{2}{*}{$\begin{array}{c}\text { Pampus } \\
\text { argentus }\end{array}$} & Busheher & $26-45$ & 37 & $319-469$ & 421.4 & 10 \\
\cline { 2 - 7 } & Genaveh & $30-41$ & 35 & $345-435$ & 367.5 & 10 \\
\hline
\end{tabular}

Table 2: Average concentrations in four fish species.

\begin{tabular}{|l|c|c|}
\hline \multirow{2}{*}{ Areas } & \multicolumn{2}{|c|}{ Average concentrations of heavy metals in four fish species } \\
\cline { 2 - 3 } & $\mathrm{Pb}$ & $\mathrm{Cd}$ \\
\hline Bandar-Bushehr & 0.20 & 0.14 \\
\cline { 2 - 3 } & $(0.09-0.55)$ & $(0.02-0.4)$ \\
\hline Bandar-Genaveh & 0.16 & 0.11 \\
\cline { 2 - 3 } & $(0.01-0.3)$ & $(0.01-0.32)$ \\
\hline
\end{tabular}


Table 3: Estimated target quotients (THQ) for individual metals caused by the consumption of fish.

\begin{tabular}{|l|c|c|}
\hline & $\mathrm{Pb}$ & $\mathrm{Cd}$ \\
\hline Adults & & 0.04 \\
\hline Bandar-Bushehr & 0.01 & 0.03 \\
\hline Bandar-Genaveh & 0.01 & \\
\hline Children & & 0.06 \\
\hline Bandar-Bushehr & 0.02 & 0.04 \\
\hline Bandar-Genaveh & 0.01 & \\
\hline
\end{tabular}

\section{DISCUSIONS}

The health risks imposed by exposure to $\mathrm{Pb}$ and $\mathrm{Cd}$ to the local inhabitants in two coastal regions of Iran through the consumption of contaminated fishes were investigated based on estimated target hazard quotients (THQs). The results showed that THQ values are less than 1 for both adults and children by either consuming fish alone.

The consumption of fish provides health benefits, but some of them have high heavy metals levels, contributing to possible adverse effects, particularly in foetuses and young children. Health benefits and risks from consumption of fish have mainly focused on recreational and subsistence fish, and only more recently on commercial fish (Burger and Gochfeld, 2007a), although Yess (1993) reported on levels of canned tuna much earlier.

While the definition of subsistence is arguable, fish comprise an important part of the diet of the people living in the coastal area (Patrick, 2002; Hamrick and Smith, 2003) and especially in our study area. Providing these people with information about contaminants in the fish that they consume are thus an important public health mandates.

Oral reference doses were based on $1 \times 10 \mathrm{mg} / \mathrm{kg} /$ day for Cd (USEPA, 2000a) and 1.5 $\mathrm{mg} / \mathrm{kg} /$ day for $\mathrm{Pb}$ (USEPA, 2000). The target hazard quotients (THQs) of studied metals through consumption of fish for residents (adults and children) from the two studied districts were derived and listed in table number 3. It is shown that there are no THQ values over 1 through the consumption of fish, suggesting that health risks associated with heavy metals exposure is insignificant, the tolerable weekly $\mathrm{Pb}$ intake limit recommended by the $\mathrm{FAO} / \mathrm{WHO}$ for adults being $25 \mu \mathrm{g} / \mathrm{g}$ body weight (Wang, 2005b).

With corresponds to $3.5 \mu \mathrm{g} \mathrm{Pb} / \mathrm{kg}$ body weight/day, taking into account the average body weight of $55.9 \mathrm{~kg}$ for adults in these areas, the tolerable daily intake of $\mathrm{Pb}$ will be 200 $\mu \mathrm{g} / \mathrm{g}$.

The dietary $\mathrm{Pb}$ intake estimated for the inhabitants of the area is far below the accepted tolerable limit. The $\mathrm{Cd}$ intake through the consumption of fish is also less than the tolerable daily dietary intake limit (57-71 $\mu \mathrm{g}$ /day) sustained by FAO/WHO (Wang, 2007) (Fig. 1).

Providing information on risk from single-meal exposures, especially for pregnant women, is a risk communication challenge that we feel should be considered by the FDA. Egeland and Middaugh (1997) have called attention to the countervailing nutritional importance of fish, which increases the importance of identifying suitable local fish with low contaminant levels, especially during pregnancy. It is a matter of risk balance (Gochfeld and Burger, 2007b). 
We caution that fish consumption, is a matter of risk balancing (Egeland and Middaugh, 1997; Gochfeld and Burger, 2007b). There are clearly both benefits and risks from fish consumption, and the public should be provided with as much information as possible to allow them to maximize the positive health benefits, while minimizing the risks from contaminants. The availability of information on both of the risks and benefits of specific species of fishes from particular areas is the key for decisions about fish consumption. To be effective, development of risk communication tools should involve not only scientists, health professionals, and regulators, but the public as well (Gochfeld and Burger, 2007b).

To further elucidate the specific risk contribution in each district, detailed information on food consumption structure and the metals concentrations in these areas would hopefully be obtained by future efforts.

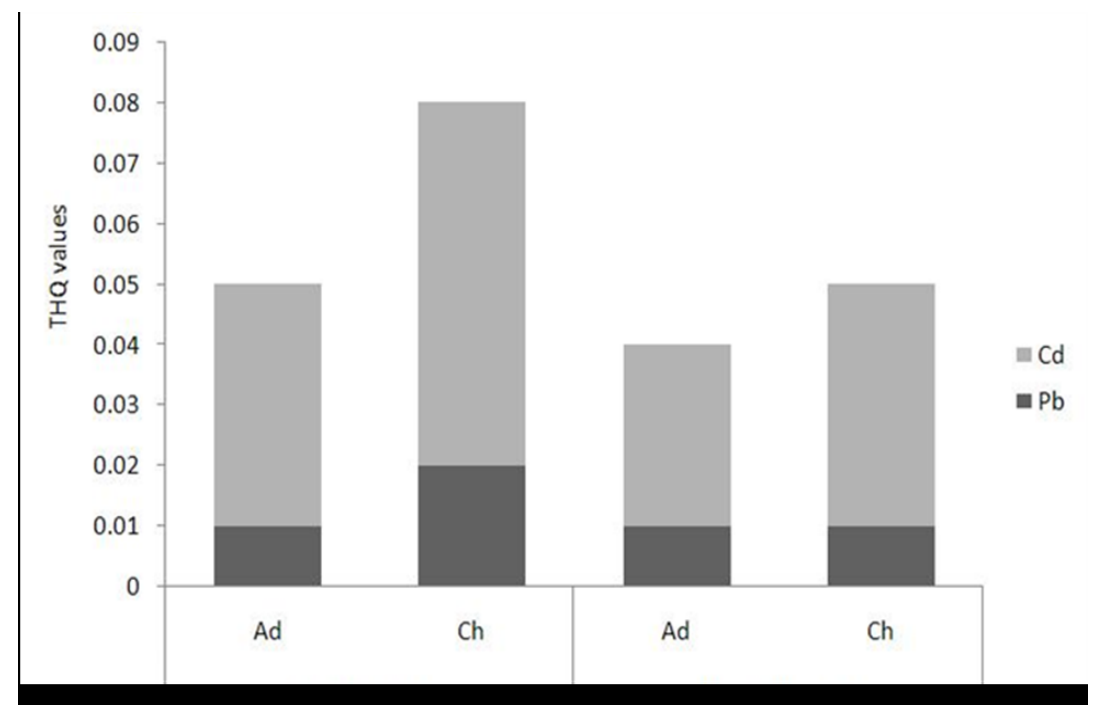

Figure 1: Total metal THQ values due to consumption of fish.

\section{ACKNOWLEDGEMENTS}

We express our special thanks to H. Pasha, who had kindly assisted us in data analysis. We are also grateful to M. Afkhami and M. Ehsanpour, for their valuable help in fish sampling and laboratory analysis.

\section{REFERENCES}

1. Anderson P. D. and Wiener J. B., 1995 - Eating fish, in: Graham J. D. and Wiener J. B. (eds), Risk Versus Risk: Tradeoffs in Protecting Health and the Environment, Harvard University Press, Cambridge, MA.

2. $\quad$ Burger J., Gochfeld M., Jeitner C., Burke S. and Stamm T., 2007a - Metal levels in flathead sole (Hippoglossoides elassodon) and great sculpin (Myoxocephalus polyacanthocephalus) from Adak Island, Alaska: potential risk to predators and fishermen, Environmental Research, 103, 62-69. 
3. Burger J. and Gochfeld M., 2007b - Risk to consumers from mercury in Pacific cod (Gadus macrocephalus) from the Aleutians: Fish age and size effects, Environmental Research, 105, 276-284.

4. Chien L. C., Hung T. C., Choang K. Y., Yeh C. Y., Meng P. J. and Shieh M. J., 2002 - Daily intake of TBT, Cu, Zn, Cd and As for fishermen in Taiwan, Science Total Environment, 285, $177-85$.

5. Crinnion W. J., 2000 - Environmental medicine, part three: long-term effects of chronic lowdose mercury exposure, Alternative Medicine Review, 5(3), 209-223.

6. Daviglus M., Sheeshka J. and Murkin E., 2002 - Health benefits from eating fish, Comments Toxicology, 8, 345-374.

7. Egeland G. M. and Middaugh J. P., 1997 - Balancing fish consumption benefits with mercury exposure, Science, 278, 1904-1906.

8. Food and Agriculture/World Health Organization (FAO/WHO), 1972 - "Evaluation of Certain Food Additives and the Contaminants Mercury, Cadmium and Lead", WHO Technical Report Series, 505, Geneva.

9. Cooper C. B., Doyle M. E. and Kipp K., 1991 - Risk of consumption of contaminated seafood, the Quincy Bay case study, Environment Health Perspectives, 90, 133-40.

10. Hamrick K. and Smith J., 2003 - Subsistence Food Use in Unalaska and Nikolski, Aleutian Pribilof Island Association, Anchorage, AL.

11. Hugas M., Tsigarida E., Robinson T. and Calistri P., 2007 - Risk assessment of biological hazards in the European Union, International Journal of Food Microbiology, 120, 131-135

12. Mora S. D., Fowler S. W., Wyse E. and Azemard S., 2004 - Distribution of heavy metals in marine bivalves, fish and coastal sediments in Gulf and Gulf of Oman, Marine pollution bulletin, 49, 410-424.

13. Patrick R., 2002 - How local Alaska native communities view the Amchitka issue, in: Proceedings of the Amchitka Long-term Stewardship Workshop, CRESP/University of Alaska, Fairbanks, AK.

14. Patterson J., 2002 - Introduction comparative dietary risk: balance the risks and benefits of fish consumption, Comments Toxicology, 8, 337-344.

15. Penny M., Kris-Etherton R. D., William S., Harris D., Lawrence J. and Appel M. D., 2002 MPH, for the Nutrition Committee "Fish Consumption, Fish Oil, Omega-3 Fatty Acids, and Cardiovascular Disease" Circulation, 106, 2747.

16. Sofuoglu S. C. and Kavcar P., 2008 - An exposure and risk assessment for fluoride and trace metals in black tea, Journal of Hazards Mater, 158, 392-400.

17. Storelli M. M., 2008 - Potential human health risks from metals $(\mathrm{Hg}, \mathrm{Cd}$, and $\mathrm{Pb}$ ) and polychlorinated biphenyls (PCBs) via seafood consumption: estimation of target hazard quotients (THQs) and toxic equivalents (TEQs), Food Chemical Toxicology, 46, 2782-2788.

18. US EPA, 2000a - Risk-based concentration table, Philadelphia PA: United States Environmental Protection Agency, Washington D. C.

19. US EPA, 2000 - Risk-Based Concentration Table, Environmental Protection Agency, Philadelphia P. A., Washington D. C., United States.

20. Wang X. L., Tao S., Dawson R. W. and Xu F. L., 2002 - Characterizing and comparing risks of polycyclic aromatic hydrocarbons in a Tianjin wastewater-irrigated area, Environmental Research, 90, 201-206.

21. WHO, 2007 - High-Level International Food Safety Forum adopts the Beijing Declaration on Food Safety, http://www.who.int/foodsafety/fs_management/meetings/forum07/en/index. html

22. Yess N. J., 1993 - Food and Drug Administration survey of methylmercury in canned tuna, Journal AOAC, 76, 36-38.

23. Wang X., Sato T., Xing B. and Tao S., 2005 - Health risks of heavy metals to the general public in Tianjin, China via consumption of vegetables and fish, Science of Total Environment, 350, 28-37. 